\title{
ORGANIZATIONAL ASPECTS OF FISCAL AUTHORITIES IN UKRAINE AND FOREIGN COUNTRIES: COMPARATIVE ANALYSIS
}

\author{
Olena Tykhonova', Oleksandr Sviderskyi², Iryna Yefremova ${ }^{3}$
}

\begin{abstract}
The aim of the article is a comparative legal study of the organizational aspects of fiscal authorities in Ukraine and in some foreign countries and so to determine ways to improve domestic legislation in this area. The subject of the study is the domestic and foreign experience of the structure and activity of fiscal authorities in such countries as the United States, the UK, France, the Republic of Latvia, the Republic of Belarus and Kazakhstan. Methodology. The study is based on the use of general scientific and special scientific methods and techniques of scientific knowledge. The historical method enabled to study the origin and formation of fiscal authorities in Ukraine. Analysis and synthesis enabled to interrogate the fiscal system of Ukraine and some foreign countries as a complex legal phenomenon, defining its essence, characteristics, and targets. The method of the system approach enabled to determine the place of individual fiscal authorities in the financial system of the country, to analyse their main responsibilities, functions and areas of activity. The comparative legal method enabled to analyse the experience of the organization and activities of fiscal authorities in foreign countries, as well as to define the ways of its implementation in the national legal system. The results of the study revealed that for today the experience of Ukraine in the organization of activity of fiscal authorities is rather progressive and modern, and the national fiscal system is characterized by consolidation of powers in coordinating and controlling taxation and customs, which defines progressiveness of our country. Practical implications. The positive experience of the fiscal organization in foreign countries suggests the expediency of including national fiscal authorities in a single centralized system of executive power, through the creation of a separate ministry. This will enable not only to improve the efficiency of generating the state budget but also in the future will lead to overcoming the gap between the tax-customs policy and its application results. Relevance/originality. A comparative analysis of the organizational aspects of fiscal authorities in foreign countries is the basis for developing priority areas for improving the fiscal system of Ukraine, identifying gaps in its work, as well as introducing in the activity of fiscal bodies the newest methods that can increase their level and bring them into line with international standards.
\end{abstract}

Key words: fiscal authorities, taxation, customs, foreign experience.

JEL Classification: P34, H21

\section{Introduction}

The welfare of any state depends on many factors, for example, the state budget is a source of accumulated financial resources which are means for the state, as the embodiment of the supreme perfect social formation, to secure its existence. Therefore, one of the key factors is the process of generating the state budget. The special official agencies, such as fiscal authorities are responsible for this activity. For that reason, the legal status and organizational aspects of the work of the latter are of particular interest, as the study of their functioning specifics will improve the professional performance of the fiscal authorities, and so will directly affect the level of state financial interest protection.

Corresponding author:

${ }^{1}$ National Academy of Internal Affairs of Ukraine, Ukraine.

E-mail: gavruha@ua.fm

${ }^{2}$ Hon. Prof. M.S. Bokarius Kharkiv Research institute of Forensic Examinations, Ukraine.

${ }^{3}$ Kharkiv National University of Internal Affairs, Ukraine.
Considering the current objectives of our state, such as the active integration into the world community, the elaboration of a strategy for fiscal consolidation involve studying the organizational matters of similar state department functioning in other countries and comparing them with national realities. From this perspective, the primary areas of Ukraine's fiscal policy improvement can be figured out, the gaps in its work that require "regulatory filling" can be identified, as well as the most recent methods can be introduced in the activities of fiscal authorities to increase their level and bring into line with the international organizational standards. 
Both domestic and foreign scientists analysed the legal status of the fiscal bodies, as well as their structural features. For example, the issues of historical development and the formation of national fiscal bodies were considered in the works of V. T. Belous, O. O. Bandurka, V. I. Poliukhovych, V. K. Shkarupa, L. M. Kasianenko and others. The theoretical legal aspects of fiscal authority functioning were covered by V. H. Demianchyshyn, M. P. Kucheriavenko, Ye. S. Vilkova, S. A. Bakanova, V. V. Labotskyi, S. M. Popov, O. H. Riabchuk, O. P. Fedotov and others. Organizational-legal aspects of the fiscal authority of foreign countries were reflected by O. B. Puhachenko, O. D. Oliinyk, D. H. Muliavka, N. P. Flisak, Ye. S. Khoroshaieva, and others. However, a qualitative comparative analysis of organizational aspects of fiscal authorities of Ukraine and foreign countries has not been carried out to date. The legal literature reveals the essence of this issue only superficially.

\section{Main material}

It should be noted that etymologically the term fiscal, from which the concept of fiscal service derives, has a wide range of definitions. Today, the dictionary literature represents the following interpretations:

1) a taleteller, an informer;

2) a spy;

3) an official who deals with state affairs;

4) an official who oversees the implementation of laws, in particular in the financial sector (Chudinov, 1894; Mikhelson, 1866; Ozhegov, Shvedov, 2006).

According to another interpretation, the term "fiscal" derives from the Latin word "fiscus," that is, a cashier, the treasury. It is used in public finances to identify either officials or sources of the flow of money into budgets (Marynchak, 2017).

Therefore, based on linguistic tendencies, fiscals or fiscal authorities are a system of state bodies and their officials that function in the sphere of generating the state budget and its monitoring. In other words, it is the branch of charging various types of duties and taxes. It is the subject of the activities of domestic fiscal authorities and institutions of foreign countries.

To begin with, for a comparative analysis, the organizational aspects of the national fiscal bodies should be covered. Historically, fiscal authorities in Ukraine traced its origin back to the 18th century. In this period, Peter I issued his Decree "On Fiscals," which introduced in the Russian Empire (which at that time included the territory of Ukraine) the position of fiscals (civil servants), who controlled and supervised over the courts and the state treasury (Tikhii, 2006; Pozharskii, 2004).

An important milestone in the development of fiscal authorities was the State Chancellery, created by Empress Catherine II as an independent financial institution. In the governorates, it was headed by vice governors, the second-highest ranking officials in the system of local government, indicating the excellent status of the newly formed body. In the Institution to Administer the Governorates as of November 7, 1775, Chapter IX "On the activities of the State Treasury Chamber," the duties of the Treasury Chamber included control over the timeliness, completeness and correctness of collection of incomes, ensuring their storage and delivery. The inadmissibility of exceeding powers by it or the interference in its activities were provided (Dzisiak, 2001; Smolkin, 1990).

During the Soviet period, in Ukraine, centralized fiscal authorities were represented by two separate departments that carried out functions related to the generating of the state budget, namely the State Tax Service of the USSR, subordinated to the Ministry of Finance of the USSR and the Ministry of Finance of the Union Republics, and the Main Directorate of the State Customs Control under the Council of Ministers of the USSR (Oliinyk, 2014; Berezhniuk, 2009).

The current State Fiscal Service of Ukraine was established by the Resolution of the Cabinet of Ministers of Ukraine no. 236 as of May 21, 2014, which approved the Regulations on the State Fiscal Service of Ukraine (hereinafter - the SFS). In accordance with this legal regulation, the SFS is a central executive body, directed and coordinated by the Cabinet of Ministers of Ukraine via the Minister of Finance, implementing state tax policy, state customs policy, the state policy on administering the single contribution to the compulsory state social insurance (hereinafter referred to as a single contribution), state policy on combating offenses in the application of tax, customs legislation, as well as legislation on payment of a single contribution (The Cabinet of Ministers of Ukraine, 2014). In its activities, the SFS is guided by the Constitution and laws of Ukraine, decrees of the President of Ukraine and resolutions of the Verkhovna Rada of Ukraine, adopted in accordance with the Constitution and laws of Ukraine, acts of the Cabinet of Ministers of Ukraine, other legislative acts (The Cabinet of Ministers of Ukraine, 2014).

It should be noted that the SFS is subject to implement a large range of objectives, the main of which are defined in the Regulation:

1) realization of the state tax policy and policy on state customs, the state policy on combating offenses during the application of tax, customs legislation; control, within the limits of authorities provided for by law, for revenues to the budgets and state target funds of taxes and fees; the state policy on monitoring the production and circulation of alcohol, alcoholic beverages and tobacco products, the state policy on administering a single contribution, as well as combating offenses in the application of legislation on payment of a single contribution; the state policy on monitoring the timely execution of settlements in foreign currency within the 
statutory period; compliance with the order of cash settlements for goods (services), as well as control over licenses for economic activities subject to licensing in accordance with the law, commercial patents;

2) making proposals to the Minister of Finance for ensuring the formation of:

- the state tax policy;

- the state policy on state customs;

- the state policy on combating offenses during the application of tax, customs legislation, monitor receipts to budgets and state trust funds of taxes and duties, customs and other payments;

- the state policy on monitoring the production and circulation of alcohol, alcoholic beverages and tobacco products;

- the state policy on administering a single contribution, as well as the combating violations in the application of legislation on payment of a single contribution;

- the state policy on monitoring the timely execution of settlements in foreign currency within the statutory period; compliance with the order of cash settlements for goods (services), as well as control over licenses for economic activities subject to licensing in accordance with the law, commercial patents (The Cabinet of Ministers of Ukraine, 2014).

The scientific views of the legal experts regarding the legal status of the SFS of Ukraine should be considered. In general, the creation of this institution and its performance are perceived as improvement of the state financial management. For example, in her scientific works, S.S. Popova has repeatedly emphasized that the formation of a civil and democratic society in our country is interrelated with the increase in the efficiency of public authorities, in particular, the state tax and customs service, since the performance of tax and customs officials affects largely the conditions for economic activities in the state and financial budgetary support for the functioning of the entire state apparatus (Popova, 2015).

According to O.O. Briginets, the SFS of Ukraine is the main instrument in ensuring the financial security of the state and a guiding element for generating the state budget of Ukraine, due to its legal status of a central executive authority, which implements the state economic policy and performs consolidated functions of tax and social payment collection (Bryhinets, 2016).

Therefore, the fiscal authorities of Ukraine are an important element of public administration, as well as an instrument for providing financial revenues to the state budget. Their activities are centralized since the central executive authorities coordinate them. In addition, the characteristic feature of the SFS of Ukraine is the combination of the several services' areas (customs and $\operatorname{tax})$ in the framework of its activities. Consolidation of functions of generating the state budget within a single body enables to improve the control over budget revenues, to protect effectively the data of legal relations from violations, as well as to ensure a stable financial system of the state in total.

Furthermore, for comparative analysis, the work of fiscal bodies in foreign countries should be studied. Primarily, the organizational aspects of fiscal agencies in the United States should be considered, because this country has one of the most powerful economies in the world, which proves the effectiveness of the internal mechanism for collecting taxes, duties and other government-determined official charges. Contrasting to Ukraine, in the United States of America, the fiscal authorities are represented by two separate departments.

With regard to the tax administration bodies, the US Federal Tax and Financial Control Service is the core of this system. The main element in its structure is the Internal Revenue Service (hereinafter referred to as the IRS), which is subordinated to the Department of the Treasury. The organizational structure of the IRS is based not on types of taxes, but on the functional features of the taxation system, that is, the structure is functional. The main structural divisions of the IRS are a tax return processing service, a tax return auditing service, a tax collection service, a criminal investigation service, a taxpayer support service, an international department, an information and computer technology department, a personnel department (Proskura, 2012).

The US Internal Revenue Service should meet three main objectives, such as:

1) to enhance voluntary compliance with tax laws;

2) to meet the interests of taxpayers and reduce the administrative burden on them as much as possible;

3 ) to enable the tax service to function better by improving the tax system and staff development, that is, ensuring the efficiency of the service by the quality of its performance and high qualifications of employees (Danilov, Flissak).

In addition, the US Internal Revenue Service is the central but not the only US tax authority that directly implements the fiscal function of the state. In the USA, as a federal state, the fiscal system has three levels:

- at the upper level, the IRS controls compliance with tax laws and collects federal taxes;

- at the middle level, state tax offices, revenue departments collect taxes and charges introduced by the state legislatures; revenue departments that are headed by state executive heads, that is, governors, consist of units that solve the issues of identification and registration of taxpayers, tax returns and remittances, calculations of taxes, their enforcement, assistance to taxpayers;

- at the lower level, local tax authorities collect taxes introduced by local authorities (Encyclopaedia Britannica; Bandurka, 2007).

The "customs" part of the US fiscal system is represented by the US Bureau of Customs and Border Protection, one of the largest and most comprehensive 
agencies of the US Department of Homeland Security, which is in charge of preventing terrorism and terrorist weapons, regulating and facilitating international trade, charging customs duties, and ensuring US Trade Legislation (Chentsov, Taranova, 2009).

The main functions of the Bureau include:

- law enforcement, which involves countering terrorism and illegal migration;

- protection of the national economy;

- protection of the environment and public health;

- preservation of cultural heritage;

- protection of the state border;

- facilitation of legitimate international trade and tourism (Savarets, 2017).

It should be noted that the structural organization of the service consists of 5 divisions: Office of Field Operations, which performs functions of customs and passport control at checkpoints and customs control zones; Border Patrol, which performs its functions outside the border crossing points; Air and Marine Operations; as well as investigative Operations Support; Trade; and Enterprise service (Savarets, 2017).

The experience of Great Britain, another financially well-developed country, is worth considering. The organizational model of fiscal authorities in this state is similar to the national one. Her Majesty's Revenue \& Customs serves as the key agency in this area, a government agency "without a ministerial portfolio", created by the Parliament Act in 2005 as a new body replacing the Internal Revenue Service and Customs and Excise (Savarets, 2017).

In accordance with its legal status, the UK's Revenue and Customs Service is the main tax and customs authority in the country that administers and enforces Statutory Payments in favour of the state, supports the stability of the tax system, as well as the prevention and termination of offenses in a certain industry. The main tasks of the service are:

- to safeguard the flow of money to the Exchequer;

- to make sure that money is available to fund the UK's public services;

- to facilitate legitimate international trade;

- to protect the UK's fiscal and economic security;

- to administer Statutory Payments, taxes and charges;

- to administer social payments, etc. (HM Revenue \& Customs: About us).

Theorganization of the authorityincludesapproximately 70 different departments and services, some of which are the Department of Customs Transformation, the Customs Department, the Department of Indirect Tax Control, the Department of Financial Operations, etc. (HM Revenue \& Customs: About us).

In France, a wide range of fiscal functions is also consolidated within a single body, the State Service for Customs and Indirect Taxes, which is subordinated to the Ministry of State Accounts. The Service has three main objectives:
1) to counteract fraud in the financial and tax sector;

2) an economic mission, that is, to make sure that the companies operating in France meet European trade standards;

3) to administer and collect taxes, statutory payments and duties (Les multiples missions de la douane française).

In the Republic of Latvia, fiscal authorities are represented by the State Revenue Service, formed by merging the State Financial Inspection and the Customs Department. It is a public authority directly subordinate to the Minister of Finance. The State Revenue Service of Latvia is responsible for the accounting of tax payments and taxpayers, administering state taxes, levies and other obligatory payments in Latvia, as well as administering taxes, levies and other mandatory payments to the EU budget and implementing customs policy (On State revenue Service).

The SRS of Latvia is one-levelled organization. It is represented by the central apparatus, the State Revenue Service and the central customer service and customs control points. The Service is headed by a Director General appointed by the Minister of Finance for a term of five years. The SRS structure has various departments, including Finance Department, Financial Police Department, National Customs Board, Customs Police Department, Tax Control Department, National Tax Board, Department of Legal Consultant, etc. (On State revenue Service; Oliinyk, Muliavka, 2016).

A characteristic feature of the fiscal authorities of Latvia is the use of the newest methods of management in their work. In particular, these include the sectoral approach to tax administration, focused on specific sectors of risk. This means that in case of identification of possible non-fulfilment of tax responsibilities, primarily preventive measures of tax administration are applied to taxpayers of this specific economic sector in order to ensure that their tax responsibilities will be fulfilled over time. Only in case of failure to achieve the strategic result, fiscal authorities use tax control (Oliinyk, Muliavka, 2016).

The foreign experience of the fiscal organization in the Italian Republic should be analysed, though the system of these bodies is rather cumbersome and ramified. O. M. Iliushyk, M. O. Pishchanska and M. Khainttsen argue that the experience of Italy is interesting, because the administration of taxes is engaged in three independent executive authorities, such as: first, the tax authorities themselves (Agenzia delle Entrate); second, the customs authorities (Agenzia delle Dogane) responsible for customs duties, as well as excise duties and VAT paid for the import of goods and services; third, the agency responsible for real estate and cadastral accounts (Agenzia del Territorio); in addition, some functions of tax administration are transferred to other bodies and organizations. For example, state organizations (such as Equitalia spa) are responsible 
for enforcement of paying legally imposed taxes, the special tax police (Guardia di Finanza) bears down on avoidance and evasion (Khainttsen, 2010; Iliushyk, Pishchanska, 2018).

Furthermore, in analysing the organizational aspects of foreign fiscal authorities, the specificities of the structure of similar departments of not only Western and European countries but also of the post-Soviet states should be considered because their legal systems have many common features with the national one.

For example, the fiscal system of one of Ukraine's closest neighbour, the Republic of Belarus, is represented by two separate authorities. For example, the Ministry of Taxes and Duties is the central body of the state administration, authorized:

- to carry out the state policy and to regulate and manage taxation;

- to exercise within its competence state regulation to ensure compliance with legislation on the production and circulation of alcoholic, inedible alcohol-containing products, inedible ethyl alcohol and tobacco products, circulation of tobacco raw materials;

- to implement state policy in gambling, including licensing such activities, as well as coordinating the republican bodies of state administration, local executive and regulatory bodies in gambling (O Ministerstve; Polozhenie o Ministerstve po nalogam i sboram Respubliki Belarus).

The Ministry has diverse responsibilities. For example, according to the legislation of the Republic of Belarus, the main objectives of this organization are:

- to ensure, within the limits of the competence, compliance with the tax legislation, as well as economic activity and licensing legislation, etc.;

accounting for total taxes and other obligatory payments due and actually paid;

- to develop proposals on tax regulation and management;

- to implement currency control;

- to organize tax inspections, etc. (O Ministerstve; Polozhenie o Ministerstve po nalogam i sboram Respubliki Belarus).

In state regulation of customs affairs, in accordance with the legislation of the country, the State Customs Committee of the Republic of Belarus is a republican government body that implements the state customs policy, as well as directly administers the customs. The Committee is subordinate to the Council of Ministers of the Republic of Belarus, and on specific issues to the President of the country. The main responsibilities of the Committee are:

- to carry out the state customs policy, direct management of the customs and to coordinate other state bodies and other organizations in this area;

- to ensure, within the limits of its competence, economic security of the Republic of Belarus, to protect its economic interests;
- to develop and apply methods and means ensuring compliance with customs legislation;

- to facilitate the acceleration of commodity circulation when importing goods into the Republic of Belarus and exporting goods from the Republic of Belarus through the customs border of the Eurasian Economic Union in the Republic of Belarus;

- to counteract smuggling and other crimes, which inquiries are within the competence of the customs authorities, administrative offenses, which are the subject of the competence of the customs authorities;

- to ensure the fulfilment of the international obligations of the Republic of Belarus relating to customs matters ( $\mathrm{O}$ nekotorykh voprosakh tamozhennykh organov).

In the Republic of Kazakhstan, the organizational principles of fiscal authority activities are characterized by many specific features. In this country, the departments function based on centralization. Yes, fiscal authorities are a part of the Ministry of Finance of the Republic of Kazakhstan. The objective of this body is also management and inter-sectoral coordination in budget planning, budget execution, accounting and financial reporting, budget accounting and budget reporting on the implementation of the republican budget and, within its competence, of local budgets, the National Fund of the Republic of Kazakhstan; in public procurements; in management of republican property; state regulation in rehabilitation and bankruptcy, counteraction to the legalization (laundering) of proceeds from crime, and financing of terrorism; the organization and implementation of single public procurement for budget programs or goods, works, services, determined by the authorized body, as well as the participation in the formation and implementation of tax policy and policy on customs, as well as in the prevention, detection, termination, disclosure, and investigation of economic and financial crimes, offenses within the limits provided for in legislation ( $\mathrm{O}$ nekotorykh voprosakh Ministerstva finansov Respubliki Kazakhstan).

The structural element of the Ministry is the State Revenue Committee. In accordance with the legislation of Kazakhstan, the latter is an agency which, within the competence of the central executive body, exercises regulatory, implementing and controlling functions in customs to ensure the completeness and timeliness of tax, customs and other mandatory payments to the budget, calculations, deductions, transfer of social payments, state regulation of production, and circulation of ethyl alcohol, alcoholic beverages and tobacco products, circulation of certain types of petroleum products and biofuels, state regulation and control for rehabilitation and bankruptcy, participation in the implementation of tax policy and customs policy, participation in the development 
and implementation of customs regulation, in the Republic of Kazakhstan, of goods movement across the customs border of the Eurasian Economic Union, their transportation on the single customs territory of the Eurasian Economic Union under customs control, temporary storage, customs declarations, release and use in accordance with customs procedures, customs control, power relations between state revenue bodies and persons exercising the rights to own, use and dispose of the specified goods within the limits stipulated by the legislation, as well as functions for the prevention, detection, termination, disclosure, and investigation of criminal and administrative offenses, which this body is charged for by the legislation of the Republic of Kazakhstan and other functions in accordance with the legislation of the Republic of Kazakhstan (Ob utverzhdenii Polozheniia o Komitete gosudarstvennykh dokhodov Ministerstva finansov Respubliki Kazakhstan).

\section{Conclusions}

Therefore, for today the experience of Ukraine in the organization of fiscal authorities is quite progressive and modern. The national fiscal system is characterized by the consolidation of powers in coordinating and controlling taxation and customs, which defines the progressiveness of our country. Analysis of foreign experience revealed that this organizational model of fiscal authorities is typical of such developed countries as Latvia, the UK, France, and Kazakhstan.

However, the positive experience of the latter suggests the expediency of including fiscal authorities in the centralized system of executive power by creating a separate ministry. This approach, in our opinion, not only will enable to improve the efficiency of generating the state budget but also in the future will lead to overcoming the gap between the tax-customs policy and its application results, because the latter will be designed and implemented by a single, competent state authority.

\section{References:}

Chudinov, A. N. (1894). Slovar inostrannykh slov, voshedshikh v sostav russkogo yazyka [Dictionaries of foreign words that are part of the Russian language]. SPb. (in Russian)

Mikhelson, A. D. (1866). 30000 inostrannykh slov, voshedshikh v upotreblenie v russkii yazyk s obiasneniem ikh kornei $[30,000$ foreign words that came into use in the Russian language with an explanation of their roots]. M. (in Russian)

Ozhegov, S. I., Shvedov, N. Yu. (2006). Tolkovyi slovar russkogo yazyka [Explanatory dictionary of the Russian language]. M.: ITI Technologies. (in Russian)

Marynchak, Ye. S. (2017). Pytannia zakonodavchoho vyznachennia pravovoho statusu osoby, yak zoboviazanoi storony u finansovykh pravovidnosynakh [Issues of legal definition of legal status of a person as an obliged party in financial legal relations]. Administratyvne pravo i protses, 1(19), 111-117. (in Ukrainian)

Tikhii, R. S. (2006). Problemy pravovogo regulirovaniia administrativnykh protsedur v Rossiyskoi Federatsii [Problems of legal regulation of administrative procedures in the Russian Federation] (Dissertation). Tiumen: RGB. (in Russian)

Pozharskii, D. V. (2004). Kontrolno-nadzornaia funktsiia sovremennogo gosudarstva [Control and supervisory function of the modern state] (Dissertation). Moscow: RGB. (in Russian)

Dzisiak, O. P. (2001). Pravovyi status mistsevykh orhaniv podatkovoi sluzhby v Ukraini [Legal status of local tax authorities in Ukraine] (Dissertation). Kyiv: National Academy of Internal Affairs of Ukraine. (in Ukrainian)

Smolkin, I. (1990). Otkupnaia sistema v dorevoliutsionnoi Rossii [Payment system in pre-revolutionary Russia]. Vestnik MGU, 2, 52-57. (in Russian)

Oliinyk, O. D. (2014). Deiaki pytannia shchodo henezysu rozvytku fiskalnykh orhaniv v Ukraini [Some issues on the genesis of the development of fiscal authorities in Ukraine]. Naukovyi visnyk Khersonskoho derzhavnoho universytetu, 6-1(2), 211-214. (in Ukrainian)

Berezhniuk, I. H. (2009). Henetyko-prohnostychnyi zriz systemy upravlinnia mytnoiu spravoiu v Ukraini [Genetic and prognostic study of the customs management system in Ukraine. Economics]. Visnyk Akademii mytnoii sluzhby Ukrainy. Ekonomika, 1, 69-80. (in Ukrainian)

The Cabinet of Ministers of Ukraine (2014). Pro Derzhavnu fiskalnu sluzhbu Ukrainy [On the State Fiscal Service of Ukraine] (Resolution no. 236 of May 21, 2014). Ofitsiynyi visnyk Ukrainy, 55, 1507. (in Ukrainian)

Popova, S. M. (2015). Azhministratyvno-pravovyi status orhaniv derzhavnoho finansovoho kontroliu v umovakh reformuvannia mizhbiudzhetnykh vidnosyn [The administrative and legal status of the bodies of state financial control in the conditions of reforming inter-budgetary relations]. Nashe pravo, 2, 35-41. (in Ukrainian)

Bryhinets, O. O. (2016). Mistse Derzhavnoi fiskalnoi sluzhby Ukrainy v protsesi realizatsii finansovoi bezpeky derzhavy [Place of the State fiscal service of Ukraine in the process of implementing financial security of the state]. Naukovyi visnyk Mizhnarodnoho humanitarnoho universytetu, 22, 60-63. (in Ukrainian)

Proskura, K. P. (2012). Zarubizhnyi dosvid orhanizatsii podatkovoho administruvannia [Foreign experience in the organization of tax administration]. Ekonomichnyi chasopys-XXI, 7-8, 30-33. (in Ukrainian)

Danilov, O. D., Flissak, N. P. Podatkova systema ta shliakhy yii reformuvannia: Navchalnyi posibnyk [The tax system and the ways of its reformation: A teaching manual]. K.: Parliamentary Publishing House. (in Ukrainian) 
Encyclopaedia Britannica in 30 Volumes. (1997). Vol. 17.

Bandurka, O. O. (2007). Upravlinnia derzhavnoiu podatkovoiu sluzhboiu v Ukraini: orhanizatsiyno-pravovi aspekty [Management of the State Tax Service in Ukraine: Organizational and legal aspects] (Dissertation). Kyiv: Kiev International University. (in Ukrainian)

Chentsov, V., Taranova, S. (2009). Upravlinnia mytnoiu spravoiu v SshA: orhanizatsiyni aspekty [Management of customs in the USA: Organizational aspects]. Derzhavne upravlinnia ta mistseve samovriaduvannia: zbirnyk naukovykh prats, 3(3). (in Ukrainian)

Savarets, A. (2017). Ukrainskyi ta zarubizhnyi dosvid pobudovy mytnykh orhaniv: rekomendatsii dlia suchasnoi Ukrainy [Ukrainian and foreign experience of customs authority structure: Recommendations for modern Ukraine]. Kyiv: Institute for Economic Research and Policy Consulting. (in Ukrainian)

HM Revenue \& Customs: About us. In UK Government portal. Retrieved from: https://www.gov.uk/government/ organisations/hm-revenue-customs/about

Les multiples missions de la douane française. In French Government portal. Retrieved from: http://www.douane.gouv.fr/ articles/a11602-les-multiples-missions-de-la-douane-francaise (in French)

On State revenue Service (The Law of Latvia of October 28, 1993). Retrieved from: https://www.vid.gov.lv/en/ about-us-0

Oliinyk, O. D., Muliavka D. H. (2016). Pravovyi status fiskalnykh orhaniv Ukrainy ta derzhav-chleniv Yevropeyskoho soiuzu [Legal status of fiscal authorities of Ukraine and the European Union member states] (Monograph). Irpen: State Fiscal Service of Ukraine National University of State Tax Service of Ukraine. (in Ukrainian)

Khainttsen, M. (2010). Administratyvni protsedury u finansovii sferi v FRN [Administrative procedures in the financial sector in the Federal Republic of Germany]. Administratyvni protsedury v ekonomitsi: problemy vdoskonalennia pravovoho rehuliuvannia. St. Petersburg. (in Ukrainian)

Iliushyk, O. M., Pishchanska, M. O. (2018). Analiz pobudovy podatkovykh system u zarubizhnykh krainakh ta v Ukraini [An analysis of the structure of tax systems in foreign countries and in Ukraine]. Naukovyi visnyk Lvivskoho derzhavnoho universytetu vnutrishnikh sprav, 1, 157-165. (in Ukrainian)

O Ministerstve [On the Ministry]. In The Portal of the Ministry of Taxes and Levies of the Republic of Belarus. Retrieved from: http://www.nalog.gov.by/ru/o_ministerstve_ru/(in Russian)

Polozhenie o Ministerstve po nalogam i sboram Respubliki Belarus [Regulations on the Ministry of taxes and levies of the Republic of Belarus] (Decree no. 1592 of October 31, 2001). In The Portal of the Ministry of Taxes and Levies of the Republic of Belarus. Retrieved from: http://www.nalog.gov.by/ru/polozhenie-o-ministerstve-ru/ (in Russian)

O nekotorykh voprosakh tamozhennykh organov [On some issues of the customs authorities] (Decree no. 228 of April 21, 2008). In National Legal Portal of the Republic of Belarus. Retrieved from: http://pravo.by/ document/?guid $=3871 \& \mathrm{p} 0=\mathrm{P} 30800228$ (in Russian)

O nekotorykh voprosakh Ministerstva finansov Respubliki Kazakhstan [On some issues of the Ministry of Finance of the Republic of Kazakhstan] (Decree no. 387 of April 24, 2008). In Legislation Portal of the Republic of Kazakhstan. Retrieved from: https://online.zakon.kz/Document/?doc_id=30176584\#pos=5;-275 (in Russian)

Ob utverzhdenii Polozheniia o Komitete gosudarstvennykh dokhodov Ministerstva finansov Respubliki Kazakhstan [On approval of the Regulation on the State Revenue Committee of the Ministry of Finance of the Republic of Kazakhstan] (Order no. 306 of June 14, 2016). In Legislation Portal of the Republic of Kazakhstan. Retrieved from: https://online.zakon.kz/Document/?doc_id=33514533\#pos=14;-45 (in Russian) 